\title{
A HPV-oltás és a szülői egészségértés - kanyargós út az oltásig
}

\author{
HPV vaccination and parental health literacy - the winding path \\ leading to vaccination
}

Szerző: Kun Eszter ${ }^{a} \bowtie$, Gács Zsófiab ${ }^{b}$ Benedek Angélac, Mészner Zsófia ${ }^{d}$, Koltai Júliaa

a: Szinapszis Piackutató és Tanácsadó Kft., Budapest-Debrecen, b: Semmelweis Egyetem II. sz. Gyermekgyógyászati Klinika, Budapest, c: MSD Pharma Hungary Kft., d: EMMI, Alapellátás- Fejlesztési és Módszertani Főosztály Alapellátási Osztály és Védőoltási Tanácsadó, e: MTA Társadalomtudományi Kutatóközpont és ELTE Társadalomtudományi Kar, Empirikus Tanulmányok Intézete

Beküldve: 2017. 09. 12.

doi: 10.24365/ef.v58i4.186

Bevezetés: Az ajánlott védőoltások felvételét sok tényező befolyásolja, azonban eddig nem volt pontos ismeretünk arról, hogy a HPV-oltás beadatásáról milyen szempontok alapján hoznak döntést a szülők. Az egészségértés (health literacy) szintje kulcstényező az egészségmegőrzés és a jóllét fenntartásában, így növekvő szerepet játszik a nemzetközi szakmapolitikai programok kidolgozásánál. A szülői egészségértés nemcsak a gyerek egészségét befolyásolja, hanem hatással van a következő felnőtt generáció prevenciós attitűdjére is.

Módszerek: Vizsgálatunkban a szülói egészségértés, a HPV-vel (humán papillomavírus) kapcsolatos ismeretek és a kötelezően választható HPV-oltás felvétele között kerestünk kapcsolatot. Országos reprezentatív kutatás keretében 430 szülővel vettük fel a kérdőívet (kiegészített HLSEU-Q16).

Eredmények: A szülők 76\%-ának általános egészségértése megfelelő volt, a HPV-oltást is $87 \%$-uk ismerte. Ugyanakkor a HPV-vel kapcsolatos tudásuk ennél kisebb mértékben volt pontos. Az oltás beadatása a demográfiai mutatók közül az iskolázottsággal áll fordított arányban.

Következtetések: A döntési folyamat elemzésére használt útmodell alapján az egészségértés nincs közvetlenül hatással az oltás felvételére, míg a HPV-betegséggel és -védőoltással kapcsolatos tudás és az általános oltási attitűd igen. Vizsgálatunk alapján a célcsoport magasabb ismereti szintjének elérésével ezen kulcstémákban a HPV-oltás felvételének aránya növelhető lehet a magyar populációban. A hatékony ismeretszint-növelés a különböző egészségértési szegmensek számára célzottan differenciált tartalommal, nyelvezettel és kommunikációscsatorna-használattal elérhető.

Kulcsszavak: egészségértés; HPV; védőoltás; szülők; szülői; reprezentatív kérdőíves kutatás

Introduction: The acceptance and usage of recommended vaccines is influenced by many factors, but so far there was no clear understanding of the considerations parents base their decision on regarding HPV (Human Papilloma Virus) vaccination. The level of health literacy is a key factor in maintaining health and well-being, thus it plays an increasing role in developing international policy frameworks. Parental health literacy not only influences the health of children, but also affects the preventive attitude of the next adult generation.

Methods: Our study aimed to describe the relationship between parental health literacy, HPV related knowledge and the decision whether to inoculate children with state provided HPV vaccine. In a nationally representative research, we surveyed 430 parents (supplemented HLSEU-Q16. 
Results: The overall health literacy was adequate among $76 \%$ of parents and $87 \%$ of them was aware of the existence of HPV vaccines. However, their knowledge of HPV was less accurate. The decision to inoculate their children was inversely proportional to the level of education. According to the path analysis used to model the decision process, health literacy does not have a direct impact on vaccine uptake, while knowledge about the HPV disease and vaccination as well as general vaccination attitude do.

Conclusions: Based on our research, a higher level of knowledge achieved in the target group in these key areas can increase the proportion of HPV vaccination in the Hungarian population. Efficient knowledge transfer requires targeted, differentiated content, language and communication channels for different health literacy segments.

Keywords: health literacy; HPV; vaccine; parent; parental; representative survey

\section{BEVEZETÉS}

A védőoltások elfogadása pontos mérőszáma az egészségügyi prevenciónak, ugyanakkor a nem kötelező védőoltások felvételét sokféle szempont befolyásolhatja.

A health literacy vagy egészségértés fontos meghatározója az egészséggel kapcsolatos döntéseknek. A WHO definíciója szerint ugyanis az egészségértés az adott egyén mindazon ismeretanyagának, motivációjának, kompetenciájának szintje, amely az illető egészséggel kapcsolatos információkhoz való hozzáférését, ezek megértését és mindezek alapján az egészségével kapcsolatos döntései meghozatalát szolgálják. Az Egészségügyi Világszervezet európai egészségpolitikai programjában az egészségértés szintje mint az egészségmegőrzés és a jóllét fenntartásának záloga szerepel. [1. ábra] ${ }^{1,2}$

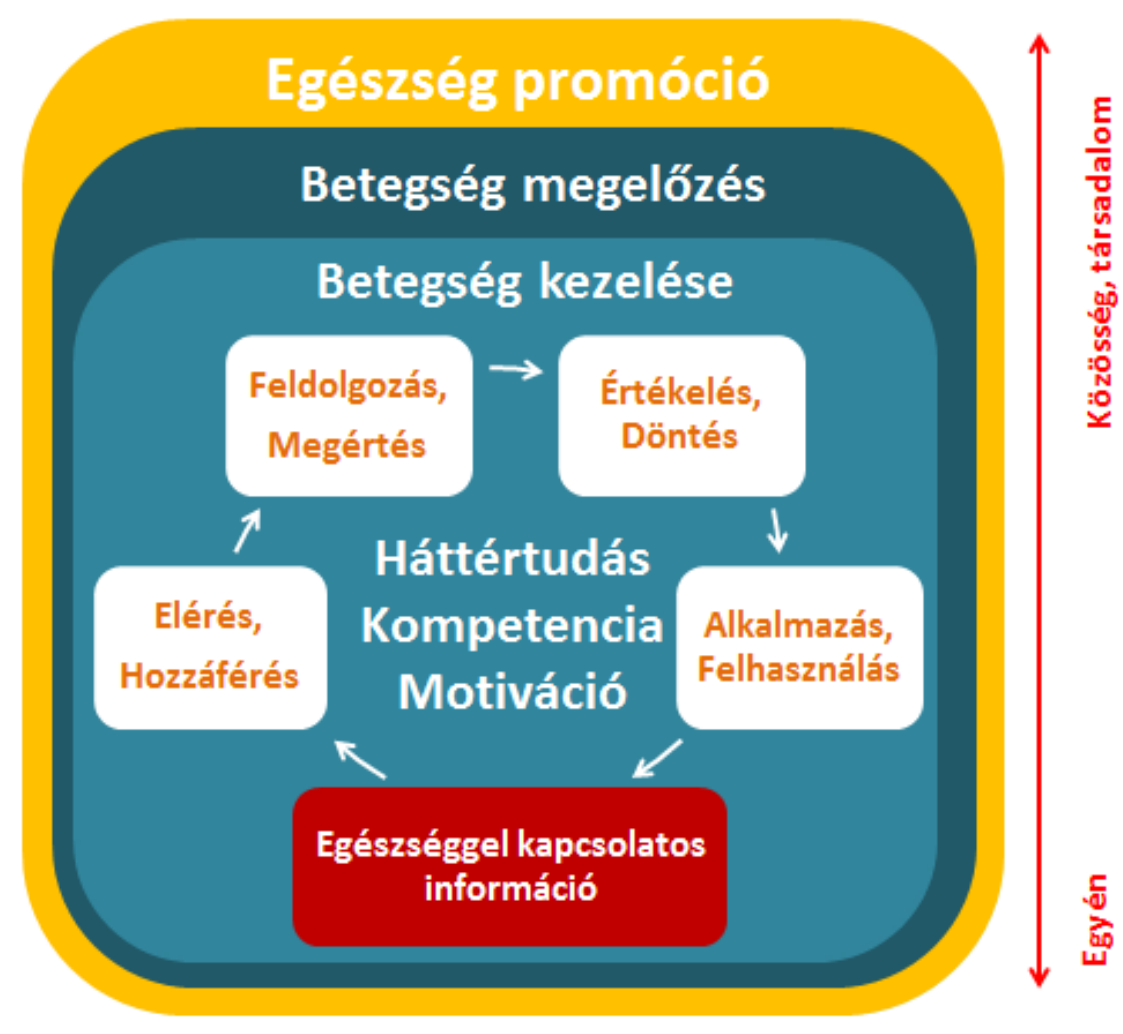

Forrás: WHO, 2013 szerint, adaptálva: Sørensen K et al. ${ }^{2}$ 
A szülői egészségértés (parental health literacy) vagyis a szülőknek a gyermek egészségével kapcsolatos döntésekhez használt tudása, ismeretanyaga, magabiztossága stb. - külön figyelmet érdemel, hiszen nemcsak a gyerekek aktuális egészségét befolyásolja, hanem hatással van a leendő felnőtt generáció egészségi állapotára, egészségügyi kiadásaira és az egészséggel kapcsolatos tudására és döntési útjaira is. 3, 4, 5, 6

Az egészségértés egyik dimenziója épp a betegségek megelőzésével kapcsolatos készségek és képességek milyensége. $7,8,9,10,11$

A humán papillomavírus (HPV) elleni oltás az elsődleges preventív eszköze a HPV-fertőzéssel összefüggő megbetegedéseknek. Szervezett oltási program 2014 óta múködik hazánkban, amelynek keretében a 12. életévüket betöltött és az általános iskola 7. osztályába járó lányok kapnak oltást kötelezően választható formában. Nemzetközi összevetésben az átoltottság magas (80\%), azonban a szülők 1/5-e visszautasítja a térítésmentes oltás beadatását. ${ }^{12}$

A szülók egészséggel kapcsolatos döntéseinek meghozatalában a hiteles szakemberként megjelenő kezelőorvos, gyermekorvos vagy védőnő szerepe esszenciális az ismeretanyag átadásában. ${ }^{7,}{ }^{13}$ Ugyanakkor feltételezhető, hogy a döntés meghozatalában a nem tudásnak, a félinformációknak vagy épp a tévhiteknek is fontos szerepük lehet - ezek adott esetben akár az oltási programok sikerét

is veszélyeztethetik. ${ }^{14}$

Ismeretes, hogy a kiegyensúlyozott, pontos tájékoztatásnak, célzott edukációnak egyértelmúen jó hatása van a védőoltások felvételét tekintve. ${ }^{11,15}$

A tájékozott döntéshez megfelelő, kiegyensúlyozott tájékoztatásra van szükség, amiben a HPV-oltás esetében az iskolai egészségnevelés mellett a családorvos, a nőgyógyász, az (iskolai) védőnő és az iskolaorvos szerepe egyaránt fontos - az ő munkájukat is segíti annak megismerése, hogy a szülők döntéseire mely tudás- és attitűdelemek gyakorolnak közvetlen hatást. Kutatásunk célja az volt, hogy meghatározzuk a szülők általános és HPV-hez köthető egészségértését, és vizsgáljuk, az oltás felvételéről szóló döntés meghozatalában milyen elemek, milyen súllyal esnek latba.

\section{MÓDSZEREK}

Az egészségértési készségeket, képességeket a HLSEU Q16 kérdőív ${ }^{9}, 13,16,17$ felhasználásával mértük, amely a HLS-EU Q47 kérdőív validált rövidített

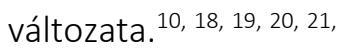

Ezt kiegészítettük a humán papillomavírussal kapcsolatos hiteket, ismereteket, félelmeket és a HPVoltásról szerzett tudást vizsgáló kérdésekkel.

Az oltási döntések meghozatalával kapcsolatos kompetenciát egy olyan index segítségével mértük, amelyet négy darab, a HLS-EU Q47-ben található, oltással kapcsolatos változóból készítettünk. (Menynyire esik nehezére: ...információt találni a szükséges védőoltásokkal és szürővizsgálatokkal kapcsolatban?; ...megérteni, hogy miért van szüksége védőoltásokra?; ...megitélni, mely védőoltásokra lehet szüksége?; ...eldönteni, hogy szüksége van-e influenza elleni védőoltásra?)

A 430 háztartást felölelő adatfelvétel 2017 márciusában zajlott az EUROBAROMETER mintavételi szabályainak megfelelő módon, személyes CAPI (Computer-assisted personal interviewing) megkérdezéssel. A minta reprezentatív volt a 0-18 éves gyermekeket nevelő magyar háztartásokra, a válaszadók a háztartásban élő gyermekek egészségével-betegségével kapcsolatos feladatokat legalább felerészben elvégző felnőttek voltak. A válaszadók $92 \%$-a nő, $8 \%$-a férfi volt. A háztartásokban átlagosan 1,9 gyermeket neveltek, az átlagos háztartásnagyság 3,9 fő volt.

\section{EREDMÉNYEK ÉS MEGBESZÉLÉS}

Kutatásunk során a vakcinák kapcsán kiemelt figyelmet szenteltünk a szülők HPV-vel kapcsolatos ismereteinek, általános és gyermekspecifikus egészségértésének, tudásának, problémamegoldási készségeinek, illetve annak, hogy ezen készségek és ismeretek hogyan befolyásolják a HPV-oltással kapcsolatos döntéseiket. A vizsgált témakörökben létrehozott összetett mérőszámok, indexek lehetővé tették komplex összefüggések vizsgálatát:

1. egészségértés (HLS-EU Q16 összesitett egészségértési index);

2. tudáselemek, ismeretek (HPV-betegséggel kapcsolatos tudás, HPV-oltással kapcsolatos tudás) 
és egyedi változóként a HPV-oltás létezésének ismeretét is bevontuk az elemzésbe;

3. hitek, attitűdök (betegségtöl való félelem);

4. vakcináció (a HLS-EU47-ből 4 további változóból képzett HLS-EU oltási kompetencia index) és a modellbe egyedi változóként bevontuk az általános oltási attitüdöt. (Ön szerint mennyire járul hozzá az ajánlott védőoltás egy csecsemő védelméhez a különböző betegségek kialakulásától?)
Korábbi adatokból ismert, hogy Magyarországon a felnőtt korú lakosság felének okoz problémát az egészségükkel kapcsolatos információk megszerzése, feldolgozása és felhasználása. ${ }^{18,19}$ Jelen vizsgálatunk eredményei azt mutatják, hogy ez az arány gyermeket nevelő szülők között sokkal kedvezőbb: mindössze a válaszadók 24\%-ánál találkoztunk korlátozott egészségértéssel [1. táblázat].

1. táblázat: Az összesitett egészségértési index eloszlása a küszöbértékek menti kategóriákban Magyarországon és a magyar szülökre (sorszázalékok)

\begin{tabular}{|c|c|c|c|c|c|}
\hline $\begin{array}{c}\text { HLS- EU Q16 } \\
\text { Összesített egészségértési index }\end{array}$ & \multicolumn{2}{|c|}{ Korlátozott } & $\begin{array}{l}\text { Elégséges+ } \\
\text { kitűnő }\end{array}$ & \multicolumn{2}{|c|}{$\begin{array}{c}\text { Átlag } \\
\text { (0-50 pontos skála) }\end{array}$} \\
\hline & elégtelen & problémás & & & \\
\hline \multirow{2}{*}{ Magyarország (n=954) } & \multirow{2}{*}{19} & \multirow{2}{*}{29} & \multirow{2}{*}{52} & Átlag & 32,3 \\
\hline & & & & Szórás & 7,8 \\
\hline \multirow{2}{*}{ Magyar szülők (n=415) } & \multirow{2}{*}{5} & \multirow{2}{*}{19} & \multirow{2}{*}{76} & Átlag & 38,0 \\
\hline & & & & Szórás & 8,2 \\
\hline
\end{tabular}

Ennek hátterében a sokkal szorosabb egészségügyi támogatást (kötelező védőnői, háziorvosi látogatások) és a gyakran előforduló egészségügyi döntési helyzeteket - fertőző betegségek, balesetek, prevenció, stb. - is feltételezhetjük.

A prevenciós egészségtudatosságot mérő alindexben elégséges és kitűnő szintet elérő magyar szülők aránya 73\% volt, de még ez is jóval magasabb eredmény, mint a korábban a teljes lakosságban mért $51 \%{ }^{19}$

A jelen kutatás egyik előzményét jelentő HSL-EUQ7 kérdőív tartalmaz 4 kérdést, amelyek az oltásokkal kapcsolatban vizsgálják az információ megszerzésének, megértésének, feldolgozásának és alkalmazásának készségeit, képességeit. [2. táblázat] ${ }^{18,19}$

2. táblázat: Az oltási kompetencia indexet alkotó kérdésekre adott válaszok eloszlásai (sorszázalékok)

\begin{tabular}{|c|c|c|c|c|c|}
\hline $\begin{array}{c}\text { Kérem, adja meg ezen a skálán, hogy Ön szerint } \\
\text { mennyire könnyứ, illetve nehéz... }\end{array}$ & $N=$ & $\begin{array}{c}\text { Nagyon } \\
\text { nehéz } \\
1\end{array}$ & $\begin{array}{c}\text { Inkább } \\
\text { nehéz } \\
2\end{array}$ & $\begin{array}{l}\text { Inkább } \\
\text { könnyü } \\
3\end{array}$ & $\begin{array}{c}\text { Nagyon } \\
\text { könnyü } \\
4\end{array}$ \\
\hline $\begin{array}{l}\text {...információt találni a szükséges védőoltásokkal és szú- } \\
\text { rővizsgálatokkal kapcsolatban. }\end{array}$ & 430 & $2 \%$ & $11 \%$ & $44 \%$ & $44 \%$ \\
\hline ...megérteni, hogy miért van szüksége védőoltásokra. & 429 & $2 \%$ & $6 \%$ & $33 \%$ & $59 \%$ \\
\hline ...megítélni, mely védőoltásokra lehet szüksége. & 429 & $4 \%$ & $17 \%$ & $37 \%$ & $42 \%$ \\
\hline $\begin{array}{l}\text {...eldönteni, hogy szüksége van-e influenza elleni védő- } \\
\text { oltásra. }\end{array}$ & 429 & $4 \%$ & $20 \%$ & $38 \%$ & $38 \%$ \\
\hline
\end{tabular}


Ezekből a kérdésekből hoztuk létre a HLS-EU oltási kompetencia indexet, hasonlóan az összesített egészségértési indexhez egy 0-tól 50-ig terjedő skálán standardizáltuk az alábbi képlet alapján:

$$
\text { index }=(\text { átlag }-1) *\left(\frac{50}{3}\right)
$$

Az így létrejött index magas értékei nagyobb kompetenciát fejeznek ki. Az oltási kompetencia index átlagos értéke 37,8 és szórása 10,7 a magyar szülők körében.

Korábbi magyar vizsgálatok azt mutatták, hogy a szülők harmada élt a nem kötelező védőoltások betegségmegelőző hatásával, ezen belül a HPV-ellenes oltást 1\%-uk adatta be gyermekének. ${ }^{20}$

Jelen vizsgálat alapján a védőoltásokba vetett bizalom magasabbnak bizonyult: a szülők $72 \%$-a állította, hogy gyermeke vagy már megkapott vagy meg fog kapni legalább egy ajánlott védőoltásti, ezen belül 11\% már beadatta a HPV elleni védőoltást gyermekének. Ugyancsak a magasabb bizalmat támasztja alá, hogy amikor arról kérdeztük a szülőket, hogy véleményük szerint mennyire járulnak hozzá az ajánlott védőoltások egy csecsemő védelméhez egy 5 -ös skálán, mindössze $1 \%$ mondta, hogy egyáltalán nem járul hozzá, 3\%, hogy alig, 10\% válaszolta, hogy "lehet, hogy igen, lehet, hogy nem”, 13\%, hogy inkább hozzájárul, $72 \%$ szerint pedig teljes mértékben hozzájárul. Ennek a megkérdezett populáció szélesebb köre mellett, legalábbis a HPV esetében, egyértelműen az oltás bevezetésétől eltelt idő is oka lehet.

A magyar kutatások nagyon változatos adatokat mutatnak a lakosságnak a HPV-vel kapcsolatos ismereteiről. Ennek leginkább az lehet az oka, hogy mind a vizsgált a populáció, mind az elemzett

tudáselemek változatosak. 2,15,16,19,22,23,24,25

Ugyanakkor egyértelműen megállapítja minden korábbi és jelen kutatás is, hogy az ismeretek elmaradnak a kívánt szinthez képest. Marek Erika és munkatársainak széles körü vizsgálataiból azt is tudjuk azonban, hogy a célzott edukációnak nemcsak az ismeretanyagra van kimutatható hatása, hanem az oltás felvételére is. ${ }^{24,26}$

Kutatásunk alapján a HPV elleni védőoltás ismert- sége magas: a megkérdezettek $87 \%$-a tudja, hogy létezik. A HPV-oltásról a létezésén túl már kevesebben tudták megmondani, hogy mire való (csökkenti a méhnyakrák kialakulásának esélyét: 76\%), illetve hogy akkor is beadható, ha már megkezdte valaki a szexuális életét (65\%), bár e két kérdésben a szülők többsége még mindig helyes választ adott. Aggasztó ugyanakkor, hogy a válaszadók 40\%-a úgy érezte, nem tudja megítélni, hogy a védőoltás okozhat-e autoimmun megbetegedést. [3. táblázat]

A HPV-betegséggel kapcsolatos tudások, hiedelmek kapcsán csak a válaszadók kis részét érintette, de fontos megemlíteni, hogy 13\%-uk igaznak gondolta, vagy nem tudta megítélni, hogy igaz-e, hogy ha egy lány szǔzen megy férjhez, akkor nem kaphat el nemi betegséget. Ez felhívja a figyelmet arra, hogy, ha szűkebb társadalmi rétegekben is, de olyan kevésbé ismert tévhitek is élhetnek, amelyek döntően befolyásolhatnak egészségügyi döntéseket.

Sokkal szomorúbb eredményeket hozott, amikor arról kérdeztük a szülőket, hogy vajon a fiúkon, férfiakon is okozhat-e rákos megbetegedést a HPV. Erre a kérdésre a válaszadók 76\%-a vagy rosszul válaszolt vagy nem tudott válaszolni.[4. táblázat]

A betegségtől való félelem kapcsán azt vizsgáltuk, a szülőket miként befolyásolják a betegségről szerzett ismeretek az ajánlott védőoltások beadatásával kapcsolatosan. Azt tapasztaltuk, hogy bár a többség figyelembe veszi a betegség súlyosságát, a fertőzés valószínūségét és a lehetséges szövődmények komolyságát, azonban ezek nem elsődleges döntési tényezők. Ahogy arról a cikk elején írtunk, a legfontosabb döntésbefolyásoló szerepük a gyermekorvosoknak (TOP3 említés: 78\%) és a védőnőknek van (TOP3 említés: 42\%). [5. táblázat]

A háztartások 33\%-ában vagy már beoltatták gyermeküket, vagy tervezik, hogy beoltatják. A HPV-oltási hajlandóságban nagy szerepet játszik a kérdéses gyermek neme: a lánygyermekek esetében $46 \%$ tervezi oltatni vagy már be is oltatta, míg fiúgyermekek esetében mindössze 19\%. [6. táblázat]

Rotavírus, bárányhimlő, influenza, HPV, gennyes agyhártyagyulladás B vagy C típusa vagy kullancs terjesztette agyhártyagyulladás ellen 
3. táblázat: Ismeretek a HPV-oltásról a magyar szülök körében (sorszázalékok)

\begin{tabular}{|c|c|c|c|}
\hline$(\mathrm{N}=430)$ & Igaz & Hamis & $\begin{array}{l}\text { Nem } \\
\text { tudja }\end{array}$ \\
\hline $\begin{array}{l}\text { A HPV/humán papillomavírus elleni védőoltás csökkenti nőknél a } \\
\text { méhnyakrák kialakulásának esélyét. }\end{array}$ & 76 & 10 & 15 \\
\hline $\begin{array}{l}\text { A HPV-oltás akkor is beadható, ha valaki már megkezdte a szexuális } \\
\text { életét. }\end{array}$ & 65 & 12 & 23 \\
\hline A HPV-oltás autoimmun megbetegedést okoz. & 13 & 48 & 40 \\
\hline
\end{tabular}

A helyes válaszok arányát dőlttel kiemeltük.

4. táblázat: Ismeretek a HPV-betegségről a magyar szülők körében (sorszázalékok)

\begin{tabular}{|c|c|c|c|}
\hline$(\mathrm{N}=430)$ & Igaz & Hamis & $\begin{array}{l}\text { Nem } \\
\text { tudja }\end{array}$ \\
\hline $\begin{array}{l}\text { Ha egy lány szűzen megy férjhez, akkor nem kaphat el nemi betegsé- } \\
\text { get később sem, mert ilyesmit csak a „könnyúvérü” lányok kapnak el. }\end{array}$ & 7 & 87 & 6 \\
\hline $\begin{array}{l}\text { A HPV/humán papillomavírus fiúkon, férfiakon is okozhat rákos be- } \\
\text { tegséget. }\end{array}$ & 24 & 40 & 36 \\
\hline
\end{tabular}

A helyes válaszok arányát dőlttel kiemeltük.

\section{5. táblázat: Félelem a betegségtöl a magyar szülők körében (sorszázalékok)}

Rangsorolja az ön döntésére ható szempontokat aszerint, hogy melyik játszotta a legfontosabb szempontot a döntésében, melyik a másodikat és így tovább! (N=430)

\begin{tabular}{|l|c|c|c|c|}
\hline & 1. említés & 2. említés & 3. említés & $\begin{array}{c}\text { További } \\
\text { említések }\end{array}$ \\
\hline $\begin{array}{l}\text { Mennyire tartom súlyosnak a betegséget, amelyre a } \\
\text { védőoltás való? }\end{array}$ & 8 & 17 & 14 & 31 \\
\hline $\begin{array}{l}\text { Mennyire látom valószínűnek, hogy gyermekem } \\
\text { elkaphatja a betegséget, amelyre a védőoltás való? }\end{array}$ & 4 & 8 & 9 & 42 \\
\hline $\begin{array}{l}\text { Mennyire tartok a betegség lehetséges szövődményei- } \\
\text { től? }\end{array}$ & 2 & 5 & 8 & 47 \\
\hline
\end{tabular}

6. táblázat: HPV-oltási hajlandóság kiskorú gyermekekre vonatkozóan (sorszázalékok)

\begin{tabular}{|l|c|c|c|}
\hline $\begin{array}{c}\text { HPV elleni oltás (Silgard, Gardasil 9, } \\
\text { Cervarix) beadatása }\end{array}$ & Összes $(\mathrm{n=430)}$ & $\begin{array}{c}\text { Fiúgyermek esetén } \\
(\mathrm{n}=217)\end{array}$ & $\begin{array}{c}\text { Lánygyermek ese- } \\
\text { tén }(\mathrm{n}=213)\end{array}$ \\
\hline Nem kapta meg, nem fogja megkapni & 48 & 60 & 36 \\
\hline Meg fogja kapni & 21 & 11 & 33 \\
\hline Már megkapta & 11 & 8 & 13 \\
\hline Nem tudja/Nem válaszol & 20 & 21 & 19 \\
\hline
\end{tabular}


A szülői egészségértés és a gyermekek oltottsága közti kapcsolat a szakirodalom alapján nagyban függ az adott társadalomban a fertőző betegségek jelenlététől, az egészségügyi ellátás elérhetőségétől, az oltások hozzáférhetőségétől is. ${ }^{17,27}$

Annak érdekében, hogy megvizsgáljuk, miként hatnak a különböző tényezők a HPV-oltási hajlandóságra, többváltozós regresszióelemzést végeztünk. E módszer nagy előnye, hogy a regressziós együtthatókat parciálisan mutatja meg, tehát úgy láthatjuk egy változó hatását az oltási hajlandóságra, hogy abból már ki van szűrve a modellben lévő összes többi változó hatása, amelyek torzíthatnák az összefüg- gést. A modellben a független változó a HPV-oltatási hajlandóság volt, magyarázó változóként pedig bevontunk a létrehozott összetett változókat, valamint attitűdre vonatkozó változókat, továbbá néhány egyedi kérdést.

Nem meglepő módon a regressziós összefüggések jelen kutatásunkban is azt mutatták ki, hogy az oltás beadatását a következő tényezők közvetlenül erősítik: (1) a betegség elleni védőoltás létezésének ismerete; (2) a betegségről és az oltásról való tudás magasabb szintje; (3) a védőoltásokkal kapcsolatos pozitív attitûd; ez utóbbiakat erősíti a magasabb egészségértési szint. [7. táblázat]

7. táblázat: A HPV-oltási hajlandóság magyarázata lineáris regressziós modellben (standardizált regressziós együtthatók)

\begin{tabular}{|l|c|}
\hline & Béta \\
\hline Összesített egészségértési index &,- 043 \\
\hline HPV betegséggel kapcsolatos tudás &, 098 \\
\hline HPV-oltással kapcsolatos tudás &, 162 \\
\hline Félelem a betegségtől &, 026 \\
\hline Általános oltási attitűd &, 139 \\
\hline HPV-oltás létezésének ismerete &, 209 \\
\hline Oltási kompetencia index &, 010 \\
\hline
\end{tabular}

A nem szignifikáns eredményeket dőlttel jelöltük. Minden más korreláció szignifikáns 0,05-ös szinten.

A HPV-oltás esetén azt tapasztaltuk, hogy a HLS-EU Q16 összesített egészségértési indexben és az oltási kompetencia indexben elért szint csak közvetett hatást fejt ki az oltás felvételére, az oltással kapcsolatos tudáson és az általános oltási attitűdön keresztül. A vizsgált háztartások szociodemográfiai jellemzői nincsenek hatással a HPV-oltás beadatására mutatott hajlandóságra. Ez alól egyedül a válaszadó szülő vagy gondviselő iskolázottsága mutat kivételt: azok körében, akik nem is tervezik beoltatni gyermeküket, szignifikánsan nagyobb arányban fordulnak elő a legfeljebb 8 általánost végzett szülők (52\%), mint azok között, akik már beoltatták vagy be fogják oltatni (22\%). Az ennél magasabb iskolai végzettségú szülők arányaiban nincs eltérés ( $z$-teszt, $p=0,05$ ).
Egy összefoglaló útmodell segítségével tártuk fel, hogy a HLS-EU Q16 összesített egészségértési indexben és az oltási kompetencia indexben elért szint, valamint a félelem a HPV-betegségtől miként, a közvetlenül hatást gyakorló változókkal milyen összefüggésben fejtik ki hatásukat a gyermekek egészségével kapcsolatos döntést hozók HPV-oltatási hajlandóságára. Az útmodell a szociológiai kutatások során oksági összefüggések feltételezésekor használatos, amelyek feltárására egymásra épülő lineáris regressziós modelleket állítunk fel. A feltételezett összefüggéseket egy diagramon ábrázoltuk, ahol a statisztikailag szignifikáns összefüggések erejét és irányát is bemutatjuk.

Azt találtuk, hogy az összesített egészségértési index magasabb értékével együtt jár az oltási 
kompetencia magasabb foka. A magasabb oltási kompetencia pedig a HPV-oltás esetében magasabb szintű tudást eredményez magáról az oltásról, és pozitívan hat az oltásokkal kapcsolatos általános attitűdre is. Ezen a két változón keresztül közvetetten a magasabb oltási kompetencia pozitív irányba befolyásolja a szülők HPV-oltatási hajlandóságát. Az általános oltási attitǔdre érdekes módon a HPVbetegségtől való félelem megléte, valamint a HPVoltás létezéséről tudás is negatívan hat, ami mindenképpen további vizsgálódásra érdemes.

Kulcskérdésnek tûnik, hogy tudomása van-e a szülőknek a HPV-oltás létezéséről. A HPV-oltás létezésének ismerete nem meglepő módon magasabb tudásszintet eredményez a HPV-oltásról és pozitívan befolyásolja a beadási hajlandóságot.
A HPV-betegségről megszerzett tudás nem függ az összesített egészségértési indextől. A HPV-betegségről való tudás viszont szignifikáns összefüggést mutat a HPV-oltásról megszerzett ismerettel. Míg az oltással kapcsolatos három tudáselemben a szülők közel fele-kétharmada jó választ adott, addig a szorosabban a betegséghez kapcsolódó elem (férfiaknál is okozhat rákot) estében ez mindössze 1/4volt, ezért felmerült, hogy az oltás kapcsán jutnak információkhoz a betegségről, nem pedig a betegségről szerzett tudás miatt informálódnak az oltásról. Mind a HPV-betegségről, mind az oltásról szerezett tudás magasabb szintje pozitívan befolyásolja a HPV-védőoltás beadatási hajlandóságot a szülők körében. [2. ábra]

2. ábra: Útmodelldiagram a HPV-oltatási hajlandóság magyarázatára (regressziós béták)

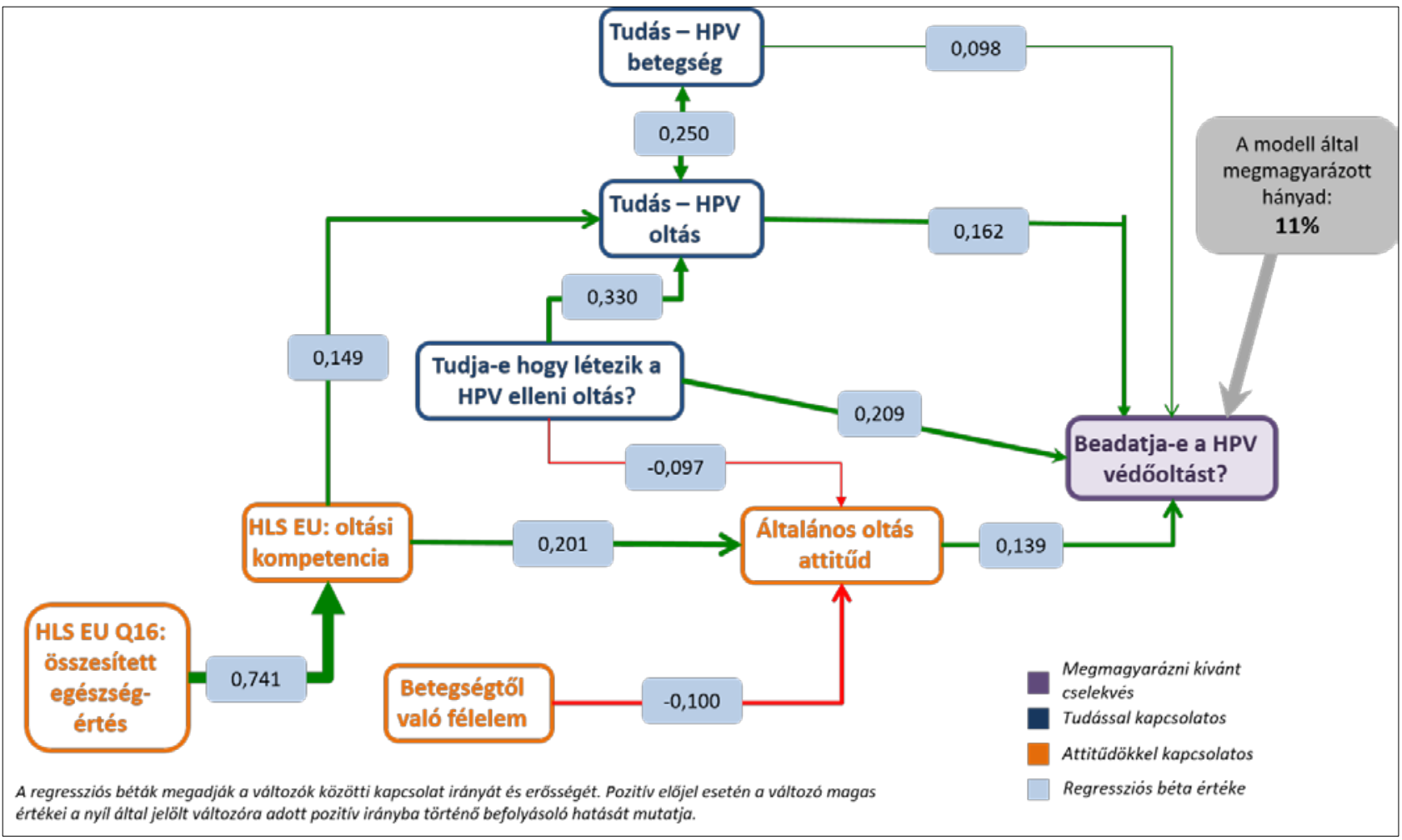

Forrás: saját szerkesztés

Természetesen a vizsgált tényezőkön kívül számos egyéb dolog befolyásolja, befolyásolhatja a szülők döntését, ilyen lehet az oltás elérhetősége és ára (ha nem elérhető ingyenesen), családi előtörténet rákos megbetegedésekkel kapcsolatban stb., ám ezek feltárása nem képezte a kutatás tárgyát.

\section{ÖSSZEGZÉS}

Kutatásunkban első alkalommal vizsgáltuk egyszerre a szülő egészségértést, a HPV-vel kapcsolatos ismereteket és a védőoltás felvételét befolyásoló tényezőket. Megállapítottuk, hogy a gyermeket 
nevelő szülők egészségértési szintje magasabb, mint az átlag felnőtt korú lakosságé hazánkban, ugyanakkor a HPV-vel kapcsolatos ismeretek jóval elmaradnak az ideálistól. Fontos felismerés, hogy a HPV-oltás felvételét nemcsak a vírussal kapcsolatos ismeretek befolyásolják, hanem az oltásnak az ismerete is.

Az útmodell használatával első alkalommal modelleztük egy ajánlott védőoltás felvételét befolyásoló tényezők erejét, irányát.

Vizsgálatunk alapján beláttuk, hogy az egészségértés, bár általánosságban fontos befolyásolója az egészséggel kapcsolatos döntéseknek, a HPV-oltással kapcsolatban a szülői populációban csak közvetett hatással van a döntésre. Eredményeink arra utalnak, hogy a HPV-fertőzés ismerete, a vírus következtében kialakuló betegségekről való tudás megléte vagy hiánya sokkal fontosabb elemei ennek a döntésnek.

Ez a felismerés azért fontos, mert lehetővé teszi, hogy célzott edukációval rövid távon és közvetlenül is hatni tudjunk a szülők döntésére, emellett a gyermekek szemléletének formálásával, az ő egészségértésük javításával az ő felnőttkori döntéseiket is az egészségmegőrzés, a megelőzés irányába fordíthatjuk.

\section{KÖSZÖNETNYILVÁNITTÁS}

A kutatást az MSD támogatta.

\section{HIVATKOZÁSOK}

\footnotetext{
${ }^{1}$ WHO Regional office for Europe. Health literacy. The solid facts. 2013. http://www.euro.who.int/_data/assets/pdf_file/0008/190655/e96854.pdf (Elérve: 2017.11.26.)

${ }^{2}$ Sørensen K, Van den Broucke S, Fullam J, et al. Health literacy and public health: A systematic review and integration of definitions and models. BMC Public Health. 2012; 12(1):80-93. doi: 10.1093/eurpub/ckv043.

${ }^{3}$ Gács Z, Berend K, Csanádi G, et al. A new questionnaire for the assessment of parental health literacy (Új kérdőív a szülői egészségműveltség mérésére) Orvosi Hetilap. 2015;156(42):1715-8. http://akademiai.com/doi/abs/10.1556/650.2015.30237 (Elérve: 2017.11.26.)

${ }^{4}$ Kumar D, Sanders L, Perrin EM, et al. Parental Understanding of Infant Health Information: Health Literacy, Numeracy, and the Parental Health Literacy Activities Test (PHLAT). Academic Pediatrics. 2010,10(5):309-16. doi:

10.1016/j.acap.2010.06.007.

${ }^{5}$ Jary D, Jary J. Collins dictionary of Sociology, 2005. 448-449.

${ }^{6}$ Vandenbosch J, Van den Broucke S, Vancorenland S, et al. Health literacy and the use of healthcare services in Belgium. J Epidemiol Community Health. 2016;0:1-7. doi: 10.1136/jech-2015-206910.

${ }^{7}$ ECDC. European Centre for Disease Prevention and Control. Let's talk about hesitancy. Stockholm: ECDC; 2016. https://ecdc.europa.eu/sites/portal/files/media/en/publications/Publications/lets-talk-about-hesitancy-vaccinationguide.pdf (Elérve: 2017.11.26.)

${ }^{8}$ ECDC. European Centre for Disease Prevention and Control. Let's talk about protection. Enhancing childhood vaccination uptake Communication guide for healthcare providers. 2012. Revised edition, Stockholm: 2016. https://ecdc.europa.eu/sites/portal/files/media/en/publications/Publications/lets-talk-about-protection-vaccinationguide.pdf (Elérve: 2017.11.26.)

${ }^{9}$ Karafillakis E, Dinca I, Apfel F, et al. Vaccine hesitancy among healthcare workers in Europe: A qualitative study. Vaccine. 2016;34(41):5013-20. doi: 10.1016/j.vaccine.2016.08.029.

${ }^{10}$ Sørensen K, Pelikan JM, Röthlin F, et al. Health literacy in Europe: comparative results of the European health literacy survey (HLS-EU). Eur J Public Health. 2015;25(6):1053-8. doi: 10.1093/eurpub/ckv043.

${ }^{11}$ Wegwarth O, Kurzenhauser-Carstens S, and G. Gigerenzer G, et al. Overcoming the knowledge-behavior gap: The effect of evidence-based HPV vaccination leaflets on understanding, intention, and actual vaccination decision. Vaccine. 2014;32(12):1388-93. doi: 10.1016/j.vaccine.2013.12.038.

12 ÁNTSZ, HPV: több mint 70 ezer oltás, 18 bejelentés, 0 súlyos oltási reakció, 2015.07.15.

https://www.antsz.hu/felso_menu/temaink/hpv/hpv_okne.html (Elérve: 2017.11.26.)

${ }^{13}$ Erős E, Supák D. Szexuális felvilágosítás - eleget teszünk-e a kamaszokért? (Sex education - do we fulfill definitely for teenagers? Gyermekgyógyászat. 2011;62(1):23-6.

${ }^{14}$ Larson HJ, de Figueiredo A, Xiahong Z, et al. The State of Vaccine Confidence 2016: Global Insights Through a 67-

Country Survey. EBioMedicine. 2016;12:295-301. doi: 10.1016/j.ebiom.2016.08.042.
} 
${ }^{15}$ Brewer NT, Hall ME, Malo TL, et al. Announcements Versus Conversations to Improve HPV Vaccination Coverage: A Randomized Trial. Pediatrics. 2017;139(1). doi: 10.1542/peds.2016-1764.

16 Jary D, Jary J. Collins dictionary of Sociology, 2005.448-449.

${ }^{17}$ Johri M, Subramanian SV, Sylvestre MP, et al. Association between maternal health literacy and child vaccination in India: a cross-sectional study. Journal of Epidemiology and Community Health. 2015;69(9):849-857. doi: 10.1136/jech2014-205436.

${ }^{18}$ Koltai J, Kun E. A magyarországi egészségértés nemzetközi összehasonlításban. Egészségfejlesztés. 2016;57(3):3-20. http://folyoirat.nefi.hu/index.php?journal=Egeszsegfejlesztes\&page=article\&op=view\&path\%5B\%5D=62 (Elérve: 2017.11.26.)

${ }^{19}$ Koltai J, Kun E. Egészségértés Magyarországon a nemzetközi eredmények tükrében. Orvostovábbképző Szemle. 2016;23(9):77-80.

http://otszonline.hu/egeszsegugyeink/cikk/egeszsegertes_magyarorszagon_a_nemzetkozi_eredmenyek_tukreben (Elérve: 2017.11.26.)

${ }^{20}$ Márton H, Szövetes M, Pásti G, et al. Hogyan védik gyermekeik egészségét a szülők? (What kind of way do the parents select to protect their children's health?). Gyermekgyógyászat. 2009;60(5):205-10.

http://mob.gyemszi.hu/detailsperm.jsp?PERMID=72914 (Elérve: 2017.11.26.)

${ }^{21}$ Pati S, Feemster KA, Mohamad Z, et al. Maternal health literacy and late initiation of immunizations among an innercity birth cohort. Matern Child Health J. 2011;15(3):386-94. doi: 10.1007/s10995-010-0580-0.

${ }^{22}$ Balla BC, Terebessy A, Tóth E, et al. A fiatal magyar férfiak attitűdje a HPV-oltással kapcsolatban/The attitude of Hungarian male high school students' concerning the HPV vaccine. Egészségtudomány. 2017;61(1):38-53.

http://egeszsegtudomany.higienikus.hu/cikk/2017-1/2017-1.pdf (Elérve: 2017.11.26.)

${ }^{23}$ Marek E, Dergez T, Rebek-Nagy G, et al. Adolescents' awareness of HPV infections and attitudes towards HPV vaccination 3 years following the introduction of the HPV vaccine in Hungary. Vaccine. 2011;29(47):8591-8. doi: 10.1016/j.vaccine.2011.09.018.

${ }^{24}$ Marek E, Dergez T, Rebek-Nagy G, et al. Effect of an educational intervention on Hungarian adolescents' awareness, beliefs and attitudes on the prevention of cervical cancer. Vaccine. 2012;30(48):6824-32. doi:

10.1016/j.vaccine.2012.09.012.

${ }^{25}$ Millei K, Vajda R, Kívés Z, et al. HPV-fertőzéssel kapcsolatos ismeretek vizsgálata édesanyák és leányaik körében. Egészségfejlesztés. 2015; 56(3):9-16. http://folyoirat.nefi.hu/in-

dex.php?journal=Egeszsegfejlesztes\&page=rt\&op=printerFriendly\&path\%5B\%5D=102\&path\%5B\%5D=0 (Elérve: 2017.11.26.)

${ }^{26}$ Marek E, Dergez T, Bozsa S, et al. Incomplete knowledge - unclarified roles in sex education: results of a national survey about human papillomavirus infections. Eur J Cancer Care (Engl). 2011;20(6):759-68. doi: 10.1111/j.13652354.2011.01258.x.

${ }^{27}$ Pati S, Feemster KA, Mohamad Z, et al., Maternal health literacy and late initiation of immunizations among an innercity birth cohort. Matern Child Health J. 2011;15(3):386-94. doi: 10.1007/s10995-010-0580-0. 